\title{
LA CONSCIENCE EXPÉRIENCIELLE DANS LA PHILOSOPHIE DE JOHN DEWEY
}

\author{
Bernard ANDRIEU \\ Universidade Paris Descartes / França \\ bandrieu59@orange.fr
}

Artigo submetido em fevereiro/2015 e aceito em abril/2015

DOI: 10.15628/dialektike.2015.2889

\section{RÉSUMÉ}

Comment l'expérience peut-elle mener à une éducation corporelle ? Une expérience sans conscience n'est pas seulement ruine de l'âme mais épuisement du corps faute d'une science réflexive constituée. Mais laquelle ? La phénoménologie a cru pouvoir réduire le vivant au vécu de la conscience avant de devoir reconnaître les difficultés d'une esthésiologie purement subjective et transcendantale. Dewey reconnaît à la physiologie de l'organisme vivant une matière suffisante pour nous indiquer par l'instinct, la fatigue, l'effort, l'habitude, le développement et la croissance des informations dont la conscience devrait s'emparer pour modifier les conditions de notre existence. L'éducation corporelle, à la différence de l'éducation physique, est dans l'usage que nous faisons de nous-mêmes et non dans le seul entretien physique d'un exercice sans réflexivité suffisante pour comparer le passé habituel et le nouveau geste.

MOTS-CLÉS : Expérience; Corporeité; Éducation; Auto-reflexivité.

\section{A CONSCIÊNCIA EXPERIENCIAL NA FILOSOFIA DE JOHN DEWEY}

\section{RESUMO}

Como a experiência pode proporcionar uma educação corporal? Uma experiência sem consciência não é apenas ruína da alma mas esgotamento do corpo, erro de uma ciência reflexiva constituída. Mas qual? A Fenomenologia acreditou poder reduzir o vivo ao vivido da consciência antes de ter que reconhecer as dificuldades de uma estesiologia puramente subjetiva e transcendental. Dewey reconhece na fisiologia do organismo vivo uma matéria suficiente para nos indicar pelo instinto, pela fadiga, pelo estresse, pelo esforço, pelo hábito, o desenvolvimento e o crescimento de informações nas quais a consciência deveria se amparar para modificar as condições da nossa existência. A educação do corpo, diferentemente da Educação Física, está no uso que fazemos de nós mesmos, não só na manutenção física de um exercício sem reflexividade suficiente para comparar o passado habitual e o novo gesto.

PALAVRAS-CHAVE: Experiência; Corporeidade; Educação; Autorreflexividade. 


\section{INTRODUCTION}

Comment l'expérience peut-elle mener à une éducation corporelle ? Une expérience sans conscience n'est pas seulement ruine de l'âme mais épuisement du corps (ANDRIEU, 2010) faute d'une science constituée réflexivement. Mais laquelle ? La phénoménologie a cru pouvoir réduire le vivant au vécu de la conscience avant de devoir reconnaître les difficultés d'une esthésiologie purement subjective et transcendantale.

Alexander est un praticien du corps qui s'est servi de son expérience corporelle personnelle pour inventer sa propre méthodologie : ayant perdu la voix alors qu'il voulait devenir acteur, il a su inventer une réflexion sur le fonctionnement de son corps vivant afin de découvrir comment respirer. En respirant mieux il a pu acquérir une meilleur posture corporelle mais aussi une méthodologie autoréflexive sur son corps vivant à partir d'une analyse ce qui en émerge dans son corps vivant : il va activer la posture pré-motrice inconsciente en la rendant de plus en plus conscience par une éducation corporelle progressive fondée sur l'attention à soi :

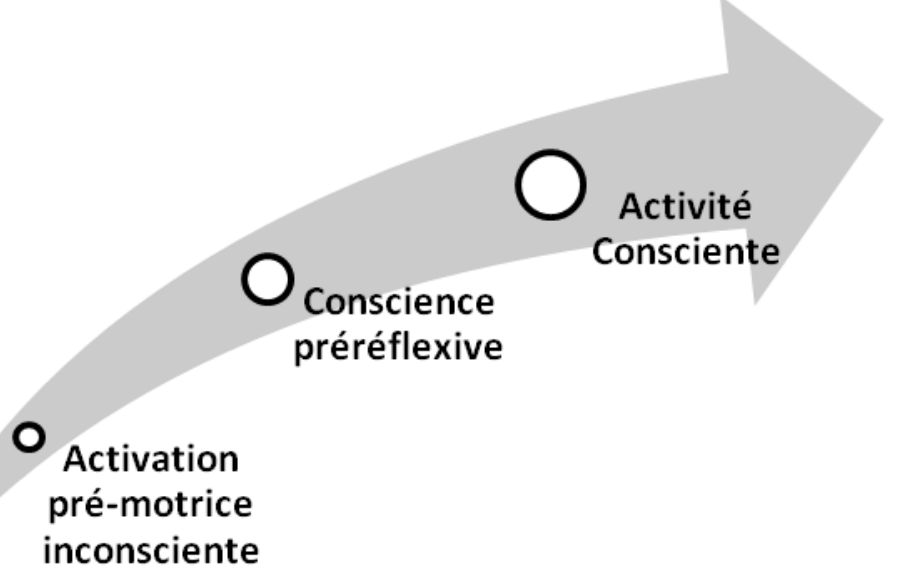

Figure 1 : Émersion

Le philosophe Dewey, qui dialogue avec Alexander et pratique avec lui, reconnaît à cette attention physiologie de l'organisme vivant une matière suffisante pour nous indiquer par l'instinct, la fatigue, l'effort, l'habitude, le développement et la croissance des informations dont la conscience devrait s'emparer pour modifier les conditions de notre existence. Le passage de la conscience préréflexive à une activité consciente suppose une continuité entre l'organisme et l'environnement afin de favoriser l'interaction corps-esprit-monde.

\subsection{La séparation organisme-environnement et ses conséquences pour l'interactionnisme}

J. Dewey est très conscient de cela quand il affirme que les sens et la chair « n'ont pas bonne presse " (DEWEY, 1931, 42). Mais son modèle interactionniste établit par le moyen des organes des sens et le dispositif moteur du corps les modes de " transformation de l'interaction en participation et en communication " (DEWEY, 1931, p. 43). Dans l'expérience immédiate sont coprésents le sensoriel, le sensationnel, le sensible, le sentimental et le sensuel sans que la 
conscience parvienne à dégager la signification incarnée de manière si directe (DEWEY, 1931, $p$. 43) que ne le fait l'expérience. L'expérience est le processus même de l'existence produit dans " I'interaction de l'être vivant et de son environnement " (DEWEY, 2006, p. 43). Mais l'expérience n'est pas le cours d'action, le processus car " nous vivons une expérience lorsque le matériau qui fait l'objet de l'expérience va jusqu'au bout de sa réalisation " (DEWEY, 1931, p. 59) : ses caractéristiques propres, son indépendance qui la rend suffisante à elle-même et son individualisation définissent une expérience vécue de laquelle une intention consciente peut émerger.

L'interaction du soi et de l'environnement est constitutive de l'expérience : "Comme chaque expérience est constituée par l'interaction entre " sujet » et " objet », entre un soi et son monde, elle n'est en elle-même ni simplement physique, ni simplement mentale. Au cours d'une expérience, les choses et évènements du monde physique et social sont transformés suivant le contexte humain dans lequel ils s'inscrivent " (DEWEY, 1931 p. 290). II y a une liaison intrinsèque du soi et du monde par laquelle le " soi interagit avec le monde " (DEWEY, 1931, p. 290) : la séparation entre organisme et environnement est une des premières raisons pour lesquelles des théories psychologiques supposent que l'expérience est quelque chose " qui n'advient qu'à l'intérieur d'un soi, d'un esprit ou d'une conscience ", perdant ainsi le sens même de l'interaction. Car en supposant que le soi est séparé du monde, l'esprit s'isole des informations fournies par son corps vivant pour ne s'en tenir qu'à une conscience du corps vécu.

Dewey refuse toute réduction de l'expérience au physicalisme (" simplement physique ») ou au mentalisme (" simplement mentale ". L'éducation ne peut être seulement physique ou intellectuelle car elle priverait le sujet de ses interactions adaptatives avec les objets environnants transformant l'organisme en corps mécanique ou automatique. La psychologie de l'éducation ne peut décrire des processus en isolant les fonctions d'un être vivant d' " avec ses environnements naturels " (DEWEY, 1931, p. 291). "La liaison intrinsèque entre soi et le monde ", " le lien unitaire " interdit tout dualisme disjoignant " en fragments séparés » les aspects intellectuels et sensoriels.

L'expérience produit, par son degré de perception esthétique, " une forme de vitalité plus intense " (DEWEY, 1931, p. 39) qui n'enferme pas dans nos sentiments et nos sensations mais qui, par « un commerce actif et alerte avec le monde, " est " synonyme d'interpénétration totale du soi avec le monde ". Ainsi l'expérience n'est pas un évènement passager dont l'intensité ne procurerait qu'une augmentation de l'esthésiologie interne. Comme " mouvement rythmé et évolution ", l'expérience " est l'accomplissement d'un organisme " par des formes encore rudimentaires de ce qui pourrait devenir de l'art. En fondant l'expérience sur la vie animale et sauvage, Dewey décrit comment le temps de l'expérience ne limite pas l'être vivant à la stricte présence de l'objet mais la projette dans les souvenirs et l'anticipation de sa signification.

\section{LE MODÈLE ÉNERGÉTIQUE DE L’ADAPTATION}

John Dewey, rappelle Richard Shusterman dans Sous l'interprétation, affirme dans Experience and nature que " l'expérience cognitive doit prendre sa source dans une expérience de nature non cognitive " après avoir précisé que " le cerveau et le système nerveux sont primitivement des organes d'action-réaction ; biologiquement, on peut affirmer sans crainte de se 
tromper que l'expérience première est un type correspondant " (DEWEY apud SHUSTERMAN, 1994, p. 83).

L'éducation est comprise par Dewey comme une nécessité biologique favorisant le contrôle des énergies environnementales, " la vie est un processus d'auto-renouvellement par action sur l'environnement » (DEWEY, 1925, p. 79). Le principe de continuité par renouvellement s'applique ici autant à l'expérience qu'à la vie elle-même, la continuité sociale de la vie étant le moyen de transmettre par le groupe les croyances et idéaux à l'individu. Cette analogie, sinon homologie par la notion de transmission, entre la société et la vie biologique, définit l'éducation comme " un processus de développement, d'enrichissement et de culture » (DEWEY, 1925, p. 89).

Mais l'apprentissage, par opposition à l'enseignement éducatif, est attaché, chez l'être humain comme chez l'animal, " à leurs objets premiers de peine ou de plaisir » (DEWEY, 1925, p. 92), ce qui définit non pas un enseignement conscient et délibéré mais une forme " d'éducation indirecte ou fortuite " (DEWEY, 1925, , p. 96) en liant des objets sociaux aux impulsions, affection ou dégoût. L'individu possède déjà en loin des tendances, comme la peur, " l'environnement ne peut tout au plus que fournir les stimuli pour appeler les réponses » (DEWEY, 1925, p. 105). Les actes de contrôle conscient ne sont pas supérieurs aux actes instinctifs ou impulsifs, car être guidé par l'intelligence prévoyante et rationnelle prive le sujet de l'expérience : " II est bon de lui permettre d'expérimenter, de découvrir par lui-même les conséquences de ses actes afin qu'il puisse agir intelligemment la fois suivante dans des circonstances semblables » (DEWEY, 1925, p. 107).

Selon une méthode rousseauiste, Dewey propose d'avoir recours à la désapprobation directe pour provoquer le trouble chez l'enfant en le détournant de la ligne impulsive. En pouvant essayer une multitude de réactions instinctives, l'enfant peut " bénéficier des expériences qui les accompagnent " (DEWEY, 1925, p. 125). La coordination progressive des gestes et des capacités visuelles du nourrisson est déjà une expérience qui prouve " un pouvoir d'adaptation spécialisé originel ", dite par Dewey " malléabilité ": " cela signifie le pouvoir de modifier les actions de base des résultats d'expériences antérieures, le pouvoir d'acquérir des dispositions, sans lequel l'acquisition des habitudes est impossible " (DEWEY, 1925, , p. 125). Dewey, à la différence du sens donné par Marcel Mauss (1936) des techniques du corps dans sa conférence d 1934, fonde I'habitus non pas sur l'incorporation mais sur le contrôle de l'environnement par l'expérience acquise ; l'habitude est une habileté, " un contrôle actif de l'environnement au moyen du contrôle des organes d'action. On a peut-être tendance à mettre l'accent sur le contrôle du corps au dépens du contrôle de l'environnement " (DEWEY, 1925, , p. 126). La capacité de varier les réponses s'effectue " jusqu'à ce que nous trouvions une façon d'agir appropriée et efficace » (DEWEY, 1925, p. 129).

Le contrôle physique se distingue du contrôle social : attraper automatiquement une balle lancée repose sur une domination, "sans but et sans signification ", seulement physique de son propre état organique, Dewey n'aperçoit pas ici le rôle du schéma corporel et son interaction environnementale inconsciente. II reste dans un modèle énergétique jouant de l'emploi particulier des conditions physiques pour modifier les dispositions. Les qualités esthétiques de l'être vivant se nourrissent de cet équilibre perdu et rétabli « entre lui et son environnement " (DEWEY, 1931, p. 36) : manque de plénitude, lutte et accomplissement, adaptation et irrégularité... définissent une expérience incertaine et mobile dont la variation des formes exprimera la dualité et la contradiction. 
Reprenant les concepts de James Baldwin (1861-1934), avant la reprise piagétienne, et sous I'influence de la philosophie évolutionniste de Spencer (1820-1903), Dewey refuse l'habituation qui suppose une conformation aux conditions fixes de l'environnement pour mettre l'accent sur l'accommodation qui traduit une adaptation de " l'environnement à nos propres activités et de nos activités à l'environnement " (DEWEY, 1925, p. 126). Un " minimum de contrôle actif " (DEWEY, 1925, , p. 128) et un maximum d'accord passif établit un équilibre entre la routinisation de l'habitude et une préférence active qu'est l'inclination. Ce sont ces habitudes actives qui font appel « à la pensée, à l'invention et à l'initiative dans l'application des capacités à de nouvelles fins » (DEWEY, 1925, p. 133).

\section{DEWEY-ALEXANDER : UNE ÉDUCATION CORPORELLE PAR LE CONTRÔLE CONSCIENT ${ }^{1}$}

Frederick Matthias Alexander (1869-1955) était un orateur Shakespearien qui a développé des problèmes d'extinction de voix. Après que les médecins l'eurent informé qu'il n'y avait pas de cause physique, il s'est soigneusement observé à l'aide de miroirs multiples. Ceci lui a permis de découvrir qu'il raidissait inutilement son corps dans son ensemble lorsqu'il se préparait à réciter ou parler. Après avoir découvert l'existence d'une certaine unité entre la tête, le cou et le dos rendant possible un meilleur accomplissement de l'être humain, il prit huit années pour appliquer avec succès ses observations empiriques afin de résoudre ses propres problèmes de voix. Alexander a pris en considération la méthode scientifique empirique comme fondement à son travail. II a utilisé l'auto-observation et le raisonnement pour rendre l'exécution physique de n'importe quel mouvement plus facile : s'asseoir, se tenir debout, marcher, utiliser ses mains et parler. Il a conçu ses méthodes afin que l'on puisse refaire l'expérimentation et s'entraîner de façon autonome, et apprendre d'une façon qui permettrait de continuer à s'améliorer à partir de n'importe quel point de départ.

Dès Jean Jacques Rousseau (1712-1778) dans l'Emile et l'éducation (1762), on estime qu'entre 2 et 12 ans l'éducation des sens doit chercher à perfectionner les enfants, avant même l'éducation de l'esprit. La vie en plein air apparait importante pour avoir une bonne santé. Le jeu a beaucoup de place dans la découverte du mouvement spontané. Dans le même temps, le chorégraphe Jean George Noverre (1722-1810), Lettres sur la danse et sur les ballets (1760), crée le ballet d'action en mettant l'accent sur le mouvement dramatique. L'éducateur saxon Johann Guts Muths (1759-1839) publie en 1793 Gymnastics for the Young, et en 1796 Games : le jeu, sans résultat quantitatif, ni équipement spécial doit favoriser la rencontre de l'écolier avec une activité concrète. La naissance de la gymnastique à partir de 1800, en Angleterre via Thomas Arnold (17951842 ) et en Suède via Per Henrik Ling (1776-1839) qui écrit Unité de la gymnastique pour le soldat

\footnotetext{
${ }^{1}$ Mathew, Ann, 1984, Implications for Education in the Work of F.M. Alexander: An Exploratory Project in a Public School Classroom, Master's Thesis, Bank Street College of Education, New York. Murray A..., "John Dewey and F.M. Alexander: 36 Years of Friendship ", The F.M. Alexander Memorial Lecture, Society of Teachers of the Alexander Technique, 1982.
} 
en 1820, pose les principes du développement de la force ${ }^{2}$ par imitation du mouvement selon le rythme du maître.

Emile Georges Demeny (1850-1917) , en 1891, publie le Manuel d'exercices gymnastiques et de Jeux scolaires. La gymnastique sera moins acrobatique, ne sera pas "athlétique", et des jeux de plein air viendront assurer l'essentiel de la réforme. Dix ans plus tard, Demeny publie Les bases scientifiques de l'éducation physique et nous donne l'explication du choix : "Ceux qui produisent le plus de travail ne sont pas toujours ceux qui possèdent les plus gros muscles; il ne faut pas confondre la force musculaire avec la résistance à la fatigue, liée, comme nous l'avons vu, aux phénomènes intimes de nutrition". Violoniste de talent, Demeny est un homme chétif qui s'est doté d'un légère couche de muscle au gymnase de Triat, mais reste plus attiré par le mouvement que par la morphologie. Son idéal sera surtout la danseuse Isadora Duncan (1878-1927). Demeny est le défenseur du mouvement complet, continu et arrondi face au mouvement linéaire et brisé jusqu'alors utilisé, que ce soit dans les exercices préliminaires de nature militaire, ou, dans les exercices de la gymnastique au sol. A côté de la danse de théâtre aux mouvements arrondis, surtout depuis la naissance du ballet romantique, la gymnastique est faite de mouvements saccadés plus proches de la pantomime. Or, en étudiant le mouvement des ailes des insectes et des oiseaux par la chronophotographie, Demeny découvre que le mouvement n'est pas linéaire et brisé mais hélicoïdal.

Jacques Dalcroze (1865-1950) utilise aussi le rythme et le mouvement. Selon lui, l'apprentissage de la musique est simplifié grâce à l'intégration corporelle des éléments rythmiques. Sa méthode vise à décomposer le rythme, pour y donner une interprétation du mouvement. Il cherche le naturel de la danse, et l'amélioration des comportements psychomoteurs, par le développement de la perception auditive, l'économie d'énergie dans le mouvement et la rapidité de réaction de l'individu.

La gymnastique douce ${ }^{3}$, à l'inverse de la gymnastique corrective de Jean-Henri Pestalozzi (1746-1827), ouvre par ses influences, l'œuvre de Rudoph Bode (1881-1970), à une conception unitaire du corps. La perte de la vitalité essentielle du mouvement naturel peut être compensée par une gymnastique qui éveille la sensation profonde du mouvement. A Berlin, son élève Hinrich Medau (1890-1952) utilise des objets comme la balle, le tambourin et le cerceau car l'objet concentre l'attention rendant les mouvements plus libres, plus naturels et plus organiques par le yoga et la maîtrise de la respiration. En Finlande Elli Björksten (1870-1947) incorpore les travaux de Dalcroze et de Georges Demeny dans l'école suédoise en l'adaptant aux femmes. Son élève Hilma Jalkanen (1889-1964) ajoute des éléments de danse et des mouvements expressifs dans ce qui deviendra la gymnastique rythmique.

\footnotetext{
${ }^{2}$ Andrieu G., 1988, L'homme et la force. Des marchands de la force au culte de la forme (XIXe et XXe siècle), Ed. Actio, pp. 183-198.

${ }^{3}$ Houareau M.J., 1978, « Les premiers pionniers », Toutes les gymnastiques douces, Paris, Retz, pp. 32-40.
} 
La conscience corporelle passe aussi par un travail sur la posture dans une conception naturelle de la gymnastique. Bess Mensendieck (1861-1957) invente un système paramédical de correction des postures. La gymnastique holistique créée par le $D^{r}$ Lili Ehrenfried (1896-1994), médecin et kinésithérapeute d'origine allemande, établie en France en 1933 pour fuir le nazisme. $\mathrm{N}$ 'ayant pas le droit de pratiquer la médecine en France, mais soucieuse de poursuivre son travail en santé, elle a introduit et développé une méthode " d'éducation du corps ", jugeant l'équilibre du corps essentiel à l'équilibre de l'esprit. Elle a, de fait, transmis l'enseignement qu'elle avait reçu, à Berlin, d'Elsa Gindler (1885-1961) qui avait mis au point une approche basée sur la prise de conscience des sensations par le mouvement et la respiration, méthode qui avait grandement contribué à la guérir de la tuberculose. La prise de conscience du mouvement et de la posture définit avec Matthias F. Alexander un contrôle volontaire du corps. Dans son livre publié en 1932, The use of the self : its conscious direction in relation to diagnosis, functionning and the control of reaction, M. F. Alexander place la médecine dans l'interaction du corps-esprit ; un acte n'est ni entièrement mental, ni entièrement physique, si bien qu'il faut éviter le dualisme. Par une direction consciente du vécu corporel, l'inhibition peut être contrôlée plutôt que soumise. Dans la vie quotidienne la somme des postures, mouvements, attentions motrices sont des objets dans lesquels la coordination, la tension et l'équilibre doivent être recherchées.

Dès son premier ouvrage Man's Supreme Inheritance Conscious Guidance and Control in Relation to Human Evolution in Civilization paru en 1910, le contrôle est défini dans ses différents niveaux :

Part One: Man's Supreme Inheritance

i From Primitive Conditions to Present Needs

ii Primitive Remedies and their Defects

iii Subconsciousness and Inhibition

iv Conscious Control

v Applied Conscious Control

vi Habits of Thought and of Body

vii Race Culture and the Training of Children

viii Evolutionary Standards and their Influence on the Crisis of 1914

\section{Part Two: Conscious Guidance and Control}

Introduction to Part Two

i Synopsis of Claim

ii The Argument

iii The Processes of Conscious Guidance and Control

iv Conscious Guidance and Control in Practice

v Conscious Guidance and Control: Apprehension and Re-Education

vi Individual Errors and Delusions

vii Notes and Instances 
Part Three: The Theory and Practice of a New Method of Respiratory Re-Education

\section{Introductory}

$i$ The Theory of Respiratory Re-Education

ii Errors to be Avoided and Facts to be Remembered in the Theory and Practice of Respiratory ReEducation

iii The Practice of Respiratory Re-Education

Concluding Remarks

\section{F. M. Alexander teaching John Dewey in c. 1917}

"Many persons have pointed out the strain which has come upon human nature in the change from a state of animal savagery to present civilization. No one, it seems to me, has grasped the meaning, dangers and possibilities of this change more lucidly and completely than Mr. Alexander. His account of the crises which have ensued upon this evolution is a contribution to a better understanding of every phase of contemporary life. His interpretation centers primarily about the crisis in the physical and moral health of the individual produced by the conflict between the functions of the brain and the nervous system on one side and the functions of digestion, circulation, respiration and the muscular system on the other; but there is no aspect of the maladjustment's of modern life which does not receive illumination." (From Dewey's introduction to Man's Supreme Inheritance, Alexander's first book, originally published in 1918)

Pour autant, Shusterman critique chez Dewey une admiration non critique pour Alexander se fonde déjà là avant d'être développée dans le dernier chapitre de Conscience du corps (SCHUSTERMAN, 2007, p. 280). Dewey y affirme que " l'étude de M. Alexander rend hommage à ce merveilleux instrument de notre vie, qu'il s'agisse de la vie mentale et morale ou de cette vie que, d'une façon quelque peu absurde, nous nommons corporelle. Si une attitude religieuse envers le corps se généralise, nous y gagnerons une atmosphère permettant d'assurer le contrôle conscient dont nous avons besoin » (DEWEY apud SCHUSTERMAN, 1994, p. 95).

Dans son second livre, publié par Alexander en 1923, Constructive Conscious Control of the Individual, Alexander met l'accent sur le jugement sensoriel et l'attention que l'être humain peut développer envers son organisme et ses besoins fondamentaux :

Part One: Sensory Appreciation in its Relation to Man's Evolutionary Development

Part Two: Sensory Appreciation in its Relation to Learning and Learning to Do

I. Education and Re-Education

II. Incorrect Conception

III. Imperfect Sensory Appreciation

IV. Illustration

V. Respiratory Mechanisms 
VI. Unduly Excited Fear Reflexes, Uncontrolled Emotions and Fixed Prejudices

VII. Psycho-Physical Equilibrium

\section{Part Three: Sensory Appreciation in its Relation to Man's Needs}

I. "Knowing Oneself"

II. Imitation

III. Concentration and the Sustained (Continuous) Projection of Orders

IV. Memory and Feeling

V. Complexity and Complications in Relation to Stress and Strain

? Part Four: Sensory Appreciation in its Relation to Happiness

Sensory Appreciation in its Relation to Happiness

Conclusions

Psycho-Physical Attitude

Appendices

a. "A New Scientific Principle" - Review by Horace Thorogood in The Star

b. "In the Name of Science" - Review in the Yorkshire Post

c. Review in The Scotsman

d. Review in The Edinburgh Evening News

e. Review in The Lancet

f. "Conscious Control" - Review in the British Medical Journal

g. "Human Skulls Dug Up by the New Psychologists" Review by Howard Devree in the New York Times

h. Review in Boston Medical and Surgical Journal, with correspondence

i. Review by Katharine B. Codman in The Public Health Nurse

j. "Increasing Consciousness" - Review in The Times Literary Supplement

En 1932 Dewey écrit une nouvelle préface pour l'ouvrage d'Alexander L'usage de soi. II met l'accent sur cette " physiologie de l'organisme vivant " plutôt que le vécu corporel qui repose sur la description empirique et pragmatique des processus modifiés par l'auto-observation : "Son observation et ses expériences s'occupent du fonctionnement réel du corps, avec l'organisme en pleine activité_et opérant dans les conditions ordinaires de la vie — se lever, s'asseoir, marcher, se tenir debout, utiliser les bras, les mains, la voix, les outils... » (DEWEY, 1932, p. 14).

"After studying over a period of years Mr. Alexander's method in actual
operation, I would stake myself upon the fact that he has applied to our
ideas and beliefs about ourselves and about our acts exactly the same
method of experimentation and of production of new sensory
observations, as tests and means of developing thought, that have been
the source of all progress in the physical sciences; and if, in any other plan,
any such use has been made of the sensory appreciation of our attitudes
and acts, if in it there has been developed a technique for creating new
sensory observations of ourselves, and if complete reliance has been
placed upon these findings, I have never heard of it. In some plans there
has been a direct appeal to "consciousness" (which merely registers bad
conditions); in some, this consciousness has been neglected entirely and 
dependence placed instead upon bodily exercises, rectifications of posture, etc. But Mr. Alexander has found a method for detecting precisely the correlations between these two members, physical-mental, of the same whole, and for creating a new sensory consciousness of new attitudes and habits. It is a discovery which makes whole all scientific discoveries, and renders them available, not for our undoing, but for human use in promoting our constructive growth and happiness." (Dewey's introduction to Constructive Conscious Control of the Individual, Alexander's second book, originally published in 1923)

\begin{abstract}
"No one would deny that we ourselves enter as an agency into whatever is attempted and done by us. That is a truism. But the hardest thing to attend to is that which is closest to ourselves, that which is most constant and familiar. And this closest "something" is, precisely, ourselves, our own habits and ways of doing things as agencies in conditioning what is tried or done by us. Through modern science we have mastered to a wonderful extent the use of things as tools for accomplishing results upon and through other things. The result is all but a universal state of confusion, discontent, and strife. The one factor which is the primary tool in the use of all these other tools--namely, ourselves--in other words, our own psycho-physical disposition, as the basic condition of our employment of all agencies and energies, has not even been studied as the central instrumentality. ....t is, however, one thing to teach the need of a return to the individual man as the ultimate agency in whatever mankind and society collectively can accomplish, to point out the necessity of straightening out this ultimate condition of whatever humanity in mass can attain. It is another thing to discover the concrete procedure by which this greatest of all tasks can be executed. And this indispensable thing is exactly what Mr. Alexander has accomplished." - (Dewey's introduction to Constructive Conscious Control of the Individual, Alexander's second book, originally published in 1923)
\end{abstract}

L'éducation corporelle, à la différence de l'éducation physique, est dans l'usage que nous faisons de nous-mêmes et non dans le seul entretien physique d'un exercice sans réflexivité suffisante pour comparer le passé habituel et le nouveau geste.

Alexander décrit lui-même cet engagement actif dans une expérience nouvelle : « Malgré cette expérience passée et la connaissance que j'en avais tirée, je m'étais embarqué dans une expérience qui mettait en jeu un nouvel usage de certaines parties de l'organisme, nouvel usage qui comprenait des phénomènes sensoriels qui ne $m^{\prime}$ 'étaient absolument pas familiers... Nous réussissons tout aussi bien à faire ce que nous avons la " volonté de faire " dans des actes qui sont à l'opposé de nos habitudes, impliquant, par conséquent, des expériences sensorielles non familières "(ALEXANDER, 1932, p. 39-40). Alexander reprend ici la différence entre le geste habituel qui répète un mauvais usage de soi, en l'occurrence le pied sur le sol qui l'engage dans une posture l'empêchant de respirer pleinement, et un changement pleinement conscient qui lui assure un nouveau contrôle de lui-même : " je devais remplacer mon ancienne direction instinctive (irraisonnée) par une nouvelle direction consciente (raisonnée). L'idée de faire passer le contrôle de l'usage des mécanismes de l'être humain du plan instinctif au plan conscient s'est 
vue justifiée déjà par des résultats obtenus dans la pratique, mais des années s'écouleront peutêtre avant que sa véritable signification ne soit pleinement reconnue comme facteur humain. " (ALEXANDER, 1932, p. 47).

\section{CONCLUSION}

Pour Dewey la connaissance établie par expérience par Alexander est de nature scientifique car elle repose sur la physiologie de la structure nerveuse et musculaire. Cette connaissance caractérisée par une coordination dont l'anatomiste est incapable, soit l'expérience d'un contrôle conscient dans l'exécution de l'acte et de la fonction exacte de chaque muscle. Le contrôle expérimental, s'il révèle bien son caractère scientifique par la preuve extrinsèque que constituent les effets du changement postural, produit un approfondissement dans la transmission et la direction des opérations par une série continue de nouveaux développements : " C'est par l'expérience personnelle que j'ai eue en tant qu'élève que je fus d'abord convaincu... Chaque leçon mène le processus un peu plus loin et confirme, sur le mode le plus intime et le plus convaincant, les affirmations qui sont faites " (DEWEY, 1932, p. 16). Notre incapacité, " dégénérescence de notre appréciation sensorielle qui forme le matériau des jugements que nous portons sur nousmêmes " (DEWEY, 1932, p. 16), à contrôler l'usage de nous-mêmes implique un mauvais usage de ce que nous faisons des autres choses. Faute d'un appareil sensoriel fiable, car construit sur de mauvaises habitudes qui nous conditionnent en corrigeant l'idée pavlovienne de réflexe conditionné, l'éducation ne peut se fonder sur « un niveau de santé psycho-physique dans lequel est inclus ce que nous appelons la moralité » (DEWEY, 1932, p. 18).

\section{BIBLIOGRAPHIE}

ALEXANDER, F.M. L'Usage de soi. Bruxelles : Ed. Contredanse, 1932.

ANDRIEU, B. (Org.). Philosophie du corps : Expérience, Interaction \& Écologie. Paris : Vrin, 2010.

DEWEY, John. Démocratie et Éducation. Paris : Armand Clin, 2011.

. Introduction. In : ALEXANDER, F.M. L'Usage de soi. Bruxelles : Ed. Contredanse, 1932.

. L'art comme expérience. CEuvres Philosophiques, tome III. Ed. J.P. Cometti,1931, trad fr 2006.

MATTHEW Ann. Implications for Education in the Work of F.M. Alexander: An Exploratory Project in a Public School Classroom, Master's Thesis, Bank Street College of Education, New York, 1984.

MAUSS, Marcel. Les techniques du corps. Journal de Psychologie, XXXII, ne, 3-4, 15 mars - 15 avril 1936.

MURRAY, A. John Dewey and F.M. Alexander: 36 Years of Friendship. In : The F.M. Alexander Memorial Lecture. Society of Teachers of the Alexander Technique, 1982.

SHUSTERMAN, Richard. Sous l'interprétation. Paris : Ed de l'Eclat, 1994.

Conscience du corps. Pour une somaesthétique. Paris : Ed l'Eclat, 2007. 